\title{
Association of nitric oxide synthase 3 gene polymorphism with the risk of type 2 diabetes
}

\author{
YASAMAN GARME $^{1}$, RAMIN SARAVANI ${ }^{1,2}$ and HAMID REZA GALAVI ${ }^{1,2}$ \\ ${ }^{1}$ Cellular and Molecular Research Center; ${ }^{2}$ Department of Clinical Biochemistry, \\ School of Medicine, Zahedan University of Medical Sciences, Zahedan 98167-43463, Iran
}

Received February 3, 2017; Accepted March 2, 2017

DOI: $10.3892 / b r .2017 .916$

\begin{abstract}
Type-2 diabetes (T2D) is a multifactorial (environmental and genetic factors) and global epidemic disease with an estimated high prevalence worldwide. Studies have indicated that nitric oxide synthase 3 (NOS3) has several important roles in the pathogenesis of T2D. The present study aims to investigate the association between NOS3 rs1800779(A/G) and T2D in an Iranian sample population. A case-control study was conducted on 250 T2D patients and 250 healthy control subjects (HCs). Genotyping of the rs1800779(A/G) variant was conducted using a Tetra-Amplification Refractory Mutation System polymerase chain reaction. The frequencies of genotypes AA, AG and GG polymorphisms were 56.8, 39.2 and $4 \%$ in the T2D group, and 42.8, 56 and $1.2 \%$ in the $\mathrm{HCs}$ group, respectively. The frequency of the minor $(\mathrm{G})$ allele was $23.6 \%$ in the T2D group and $29.2 \%$ in the HCs group. The genotype frequencies of the $\operatorname{rs} 1800779(\mathrm{~A} / \mathrm{G})$ variant demonstrated statistically significant differences between T2D and controls in a codominant model (AG vs. AA, OR=0.527, 95\% $\mathrm{CI}=0.368-0.756, \mathrm{P}<0.001)$ and dominant model $(\mathrm{AG}+\mathrm{GG}$ vs. $\mathrm{AA}, \mathrm{OR}=0.569,95 \% \mathrm{CI}=0.399-0.811, \mathrm{P}=0.002)$. There was no significant association between clinical and demographic characteristics and the NOS3 rs1800779(A/G) polymorphism in dominant status $(\mathrm{P}>0.05)$. The dominant model and $\mathrm{AG}$ genotype of NOS3 rs1800779(A/G) polymorphism may had a protective effect on T2D of Iranian population.
\end{abstract}

\section{Introduction}

Previous research has demonstrated that some factors involved in the pathogenesis of obesity-related insulin resistance and T2D cause chronic low-grade inflammation and an activation of the immune system (1). Some of the risk factors for

Correspondence to: Dr Ramin Saravani, Cellular and Molecular Research Center, Zahedan University of Medical Sciences, Khalij Fars Boulevard, Zahedan 98167-43463, Iran

E-mail: saravaniramin@yahoo.com

Key words: nitric oxide synthase, type-2 diabetes, genetic susceptibility, polymorphism the development of T2D and its macrovascular complications are systemic inflammatory markers. Conversely, in obese individuals, some organs of the body, such as the pancreas, are sites of inflammation (1). Some research suggests that there is an important association between obesity, insulin resistance, and chronic low-grade inflammation (2).

Although several environmental and lifestyle conditions are involved in diabetes, genetic factors are also important determinants (3-9). Several genes have been investigated, and nitric oxide (NO) synthase has attracted the interest of researchers because of its determinative role in production of NO in endothelial cells $(10,11)$.

Patients with diabetes, obesity and some other diseases have defects in endothelial cell function and NO production (12). The Atherosclerosis Risk in Communities Study has reported that obesity is associated with diabetes risk, and has observed that obese individuals have reduced NO bioavailability compared with individuals with normal weight $(13,14)$.

NO synthase (eNOS) (EC: 1.14.13.39) encoded on chromosome 7q35-36 by NOS3 gene produce NO from L-arginine (15). It is necessary to know that single nucleotide polymorphisms (SNPs) in NOS3 gene are associated with inflammation because inflammatory molecules regulate glucose uptake in skeletal muscles (16).

Several analyses have indicated a relationship between different NOS3 gene variants involved in endothelial function, and incidence of type-2 diabetes (17,18). Möllsten et al (19) investigated associations between diabetic nephropathy and seven eNOS3-gene polymorphisms, and they identified a significant association between the rs743507 TT-genotype and diabetic nephropathy.

Li et al (20) evaluated the association of eight SNPs of eNOS in China and reported that rs1799983 and rs891512 SNPs of eNOS were associated with T2D (19). Assuming these findings, the $e N O S$ gene may also be candidate gene of diabetes mellitus.

In the present study, a relationship between the rs1800779(A/G) and T2D was examined in an Iranian sample population.

\section{Materials and methods}

Ethics statement. Written informed consent forms were obtained from all subjects. The study was conducted following 
Table I. Polymerase chain reaction primer sequences [NOS3 rs1800779(A/G)].

\begin{tabular}{llc} 
Primer description & \multicolumn{1}{c}{ Sequence (5'-3') } & Product size (bp) \\
\hline Forward inner primer (A allele) & TAGTGGCCTTTCTCCAGCCCCTCAGAGGA & 208 \\
Reverse inner primer (G allele) & GAGTGCATGCTGGGGTTTGTAGTTCTGGGC & 256 \\
Forward outer primer & GCCCACCCCAACCTTATCCTCCACTGCT & 405 \\
Reverse outer primer & GCCGCAGGTCAGCAGAGAGACTAGGGCT & - \\
\hline
\end{tabular}

Table II. Clinical-demographic characteristics of T2D patients and controls.

\begin{tabular}{lccc}
\hline Characteristic & T2D $(\mathrm{n}=250)(\mathrm{n} \pm \mathrm{SD})$ & Controls $(\mathrm{n}=250)(\mathrm{n} \pm \mathrm{SD})$ & P-value \\
\hline Age $($ year $)$ & $54.68 \pm 10.19$ & $49.60 \pm 9.99$ & 0.554 \\
Sex $($ Female/male $)$ & $173 / 77$ & $178 / 72$ & 0.696 \\
FBS $(\mathrm{mg} / \mathrm{dl})$ & $200.63 \pm 100.58$ & $101.41 \pm 30.12$ & $<0.0001$ \\
TC $(\mathrm{mg} / \mathrm{dl})$ & $187.00 \pm 48.15$ & $179.39 \pm 36.27$ & 0.028 \\
TG $(\mathrm{mg} / \mathrm{dl})$ & $165.24 \pm 81.09$ & $143.13 \pm 81.73$ & 0.356 \\
HDL-C $(\mathrm{mg} / \mathrm{dl})$ & $52.92 \pm 19.38$ & $53.41 \pm 13.56$ & 0.020 \\
LDL-C $(\mathrm{mg} / \mathrm{dl})$ & $102.59 \pm 38.19$ & $101.50 \pm 28.74$ & 0.038 \\
BMI $\left(\mathrm{kg} / \mathrm{m}^{2}\right)$ & $27.61 \pm 5.49$ & $21.54 \pm 2.51$ & $<0.0001$ \\
\hline
\end{tabular}

FBS, fasting blood sugar; TC, total cholesterol; TG, triglyceride; HDL-C, High-density lipoprotein-cholesterol; LDL-C, Low-density lipoprotein-cholesterol; BMI, body mass index; T2D, type 2 diabetes.

Table III. Genotypic and allelic frequencies of NOS3 polymorphism (rs1800779(A/G)) in T2D patients and control subjects.

\begin{tabular}{lcccc}
\hline NOS3 polymorphism & T2D $(\%)$ & Control, $\mathrm{n}(\%)$ & OR $(95 \% \mathrm{CI})$ & P-value \\
\hline Co-dominant & & & & - \\
AA & $142(56.8)$ & $107(42.8)$ & 1.00 & $<0.001$ \\
AG & $98(39.2)$ & $140(56)$ & $0.527(0.368-0.756)$ & 0.170 \\
GG & $10(4)$ & $3(1.2)$ & $2.512(0.675-9.350)$ & - \\
A & $382(76.4)$ & $354(70.8)$ & 1.00 & 0.052 \\
G & $118(23.6)$ & $146(29.2)$ & $0.749(0.564-0.993)$ & - \\
Dominant & $142(56.8)$ & $107(42.8)$ & 1.00 & 0.002 \\
AA & $108(43.2)$ & $143(57.2)$ & $0.569(0.399-0.811)$ & 0.064 \\
AG+GG & $240(96)$ & $247(98.8)$ & & \\
Recessive & $10(4)$ & $3(1.2)$ & $3.431(0.933-12.618)$ & \\
AA+AG & & & & \\
GG & & & & \\
\hline
\end{tabular}

CI, confidence interval; OR, odds ratio; T2D, type 2 diabetes.

the guidelines of Iran Medical Research and approved by the local Ethics Committee of Medical University (Zahedan, Iran).

Case and control samples. Samples from 500 unrelated individuals were collected from the Diabetes Center in Ali Asghar Hospital (Zahedan, Iran). All samples were collected following the guidelines of according to the American Diabetes Association (21) and previous works of the authors $(7,22,23)$.

A health questionnaire on the detailed status of the subjects' disease including age, gender, body mass index (BMI), fast blood sugar (FBS), high density lipoprotein-cholesterol (HDL-C), low density lipoprotein-cholesterol (LDL-C), triglyceride (TG) and total cholesterol (TC) was administered for all participants.

Extraction of genomic DNA. A total of $5 \mathrm{ml}$ peripheral blood samples were obtained from all cases and controls in tubes containing EDTA. The standard salting-out protocol was used for extraction of genomic DNA (24). Measuring of DNA concentration was conducted by a spectrophotometer and then stored at $-20^{\circ} \mathrm{C}$. 
Genotyping. The rs1800779(A/G) of NOS3 gene was detected using Tetra ARMS-PCR method. In this technique, four primers are used, in which two primers are external and two are internal; the sequences of these four primers are demonstrated in Table I.

All PCR reactions were performed in a $20 \mu 1$ reaction volume, containing $10 \mu \mathrm{l} \mathrm{PCR} \mathrm{Master} \mathrm{Mix} \mathrm{(Ampliqon} \mathrm{A/S,}$ Odense, Denmark), $5 \mu \mathrm{l}$ DNase-free water, $1 \mu \mathrm{l}(10 \mathrm{pmol} / \mathrm{ml}$, Pishgam Biotech Co, Tehran, Iran) of each primer, and $1 \mu \mathrm{l}$ genomic DNA ( 80-100 ng/ml) in an Eppendorf thermocycler (Eppendorf AG, Hamburg, Germany). PCR was performed at $95^{\circ} \mathrm{C}$ for $5 \mathrm{~min}$ (denaturation), and then 30 cycles were performed with the following conditions: $95^{\circ} \mathrm{C}$ for $1 \mathrm{~min}$ (denaturation), $62^{\circ} \mathrm{C}$ for $45 \mathrm{sec}$ (annealing), $72^{\circ} \mathrm{C}$ for $1 \mathrm{~min}$ (extension) and $72^{\circ} \mathrm{C}$ for $5 \mathrm{~min}$ (final extension). The products were then electrophoresed using $2.5 \%$ agarose gel. DNA fragments were stained with ethidium bromide, and then the gels were read using a UV Trans illumination system (Syngene USA, Frederick, MD, USA). The sizes of products are presented in Table I.

Statistical analysis. SPSS software (version, 16.0; SPSS, Inc., Chicago IL, USA) was used for statistical analysis. Pearson's chi-squared test was used for distributions of SNPs and comparing the frequency of heterozygous and homozygous genotypes between the patients and controls. $\mathrm{P}<0.05$ was considered to indicate a statistically significant difference. Odds ratios (OR) and 95\% confidence intervals (95\% CIs) were also calculated. The Hardy Weinberg equilibrium (HWE) was calculated for both case and control groups.

\section{Results}

The study groups included $250 \mathrm{~T} 2 \mathrm{D}$ patients with an average age of 54.68 \pm 10.19 years (173 females, 77 males) and 250 healthy controls subjects (HCs) with mean age of $49.60 \pm 9.99$ years (178 females, 72 males). There was no significant difference regarding the age $(\mathrm{P}=0.554)$ and gender $(\mathrm{P}=0.696)$ of the participants between case and control groups. As demonstrated in Table II, there are significant differences regarding FBS, TC, HDL-C, LDL-C and BMI between patients with T2D and HCs $(\mathrm{P}<0.05)$.

The genotype and allele frequencies of the rs1800779(A/G) NOS3 polymorphism in both T2D and HCs are presented in Table III. The results indicated that the $\mathrm{rs} 1800779(\mathrm{~A} / \mathrm{G})$ NOS3 variant significantly decreased the risk of $\mathrm{T} 2 \mathrm{D}$ in $\mathrm{AG}$ vs. AA genotype $(\mathrm{OR}=0.527,95 \% \mathrm{CI}=0.368-0.756$, $\mathrm{P}<0.001)$. In addition, the $\mathrm{AG}+\mathrm{GG}$ vs. AA variant statistically decreased the risk of T2D in the dominant model $(\mathrm{OR}=0.569$ 95\% CI=0.399-0.811, $\mathrm{P}=0.002)$, although $\mathrm{rs} 1800779(\mathrm{~A} / \mathrm{G})$ NOS3 was not significantly associated with T2D in GG vs. AA genotype, G vs. A allele, and GG vs. AA+AG genotype in the recessive model $(\mathrm{P}>0.05)$.

The association between the rs1800779(A/G) NOS3 genotype in the dominant model (AG+GG vs. AA) and clinical-demographic characteristics of both T2D and HCs groups was conducted. As presented in Table IV, the rs1800779(A/G) NOS3 variant was not associated with clinical-demographic characteristics consisting of age, gender, FBS, TC, TG, HDL-C, LDL-C and BMI ( $\mathrm{P}>0.05)$. 
The chi-squared was used for evaluation of the HWE. The genotype of the rs1800779(A/G) NOS3 polymorphism in the case subjects was in $\mathrm{HWE}\left(\mathrm{X}^{2}=1.89, \mathrm{P}=0.1687\right)$, but in the controls was not in $\mathrm{HWE}\left(\mathrm{X}^{2}=31.4 . \mathrm{P}<0.001\right)$.

\section{Discussion}

Diabetes and obesity are important risk factors for cardiovascular and inflammatory diseases involved in the risk of diabetes $(25,26)$. Furthermore, endothelial dysfunction, characterized by both diabetes and obesity precede abnormal glucose levels characteristic of diabetes and are already present in individuals at known risk for the disease such as those with a positive family history (14,27-33).

Endothelial cells produce NO implicated in vascular relaxation in response to multiple agents including genetic defects (34). Improving endothelial function and insulin sensitivity occur because of weight loss (35). It is therefore possible to suggest that, in obese individuals, genetic polymorphisms such as NOS3 rs1800779(A/G) that influence the basal level of NO in the endothelial cells contribute to diabetes progression.

Many genes have been researched in T2D susceptibility, and the NOS3 gene has been a candidate as a genetic factor for the risk of T2D (12). Several polymorphisms of the NOS3 gene have been studied, and their association with different diseases including inflammation defects has been identified (36).

In the present study, this polymorphism was related to T2D in codominant (AG vs. AA) and dominant (AG+GG vs. AA) models, although no relationship was identified between this variant and risk/protection of T2D in allele and recessive models. Regarding the association between clinical-demographic characteristics and T2D and $\mathrm{HC}$ groups, the results presented no association in T2Ds or HCs with BMI as an obesity index. Furthermore, only very a few studies have investigated NOS3 gene polymorphisms associated with $\mathrm{T} 2 \mathrm{D}$, and research on the association between rs $1800779(\mathrm{~A} / \mathrm{G})$ in the NOS3 gene and diabetes are very rare, so the results could not be compared with similar studies; however, this gene has been investigated regarding some T2D complications.

Chen et al (37) demonstrated that NOS3 rs3918188 and NOS3 rs3918188 genetic variants were statistically associated with increased susceptibility to T2D in the homozygote comparison and recessive model in the Chinese Han population. However, Conen et al (38) identified no association between NOS3 rs1800779 and NOS3 rs3918226 polymorphisms and occurrence of T2D on a total of 24,309 Caucasian women free of diabetes at baseline in a prospective cohort study (37). In a meta-analysis performed by Zintzaras et al (39), a significant association was revealed between endothelial NO synthase gene polymorphisms (G894T) and diabetic nephropathy on 7,401 cases and 8,046 controls. Makuc et al (40) did not find any association between eNOS Glu298Asp and eNOS $4 \mathrm{a} / \mathrm{b}$ polymorphisms and diabetic nephropathy in a Slovenian population. In another investigation conducted by Chen et al (41) on two West African countries (Ghana and Nigeria), the b/b genotype of G894T polymorphisms [deletion/insertion $(4 \mathrm{a} / \mathrm{b})$ ] of the $e N O S$ gene was associated with the risk of diabetes retinopathy, while other genotypes and alleles of this polymorphism were not associated with diabetes retinopathy, hypertension or nephropathy. There was a statistically significant association between the alleles/ genotype distribution of NOS3 (ecNOS4a/4b) with chronic kidney disease (CKD), so that the $4 \mathrm{~b} / 4 \mathrm{bb}$ gene polymorphism protected from CKD in comparison between T2D patients with CKD and T2D patients without CKD in a Russian Federation population (42). Zakerjafari et al (43) presented a significant association between the NOS3 gene rs1800779 polymorphism and risk of coronary-heart disease in an Iranian population (39). Thus, the rs1800779 of NOS3 gene polymorphism may be associated with $\mathrm{T} 2 \mathrm{D}$, which is in line with findings of the current study. The differences among the above studies may be related to genetic and environmental differences of the study populations.

The deviation from HWE is not clear in the current study population; it may have some reasons, such as relatively small sample size, migration or consanguineous marriages that are common in this region of the Iran (southeast of Iran).

The current study has several limitations. Firstly, based on the published and Pubmed data (https://www.ncbi.nlm. nih.gov/snp/?term=nos3), several NOS3 polymorphisms have been identified in humans, while only one polymorphism was investigated in the present study. This SNP had previously been associated with other inflammation diseases in a previous study (43). Secondly, the authors did not consider differences by diabetes complications. Thirdly, the present study used a relatively small sample size.

In conclusion, a significant association was detected for the first time between the rs1800779(A/G) polymorphism in the NOS3 gene and T2D in an Iranian population. Different ethnic populations and large sample sizes are recommended for future studies to further assess the relationship between $\mathrm{T} 2 \mathrm{D}$ and this variant.

\section{Acknowledgements}

The authors would like to thank the Zahedan University of Medical Sciences for funding (grant no. 7224) and supporting this work and the patients and healthy subjects who willingly participated in the present study.

\section{References}

1. Esser N, Legrand-Poels S, Piette J, Scheen AJ and Paquot N: Inflammation as a link between obesity, metabolic syndrome and type 2 diabetes. Diabetes Res Clin Pract 105: 141-150, 2014.

2. Shoelson SE, Herrero L and Naaz A: Obesity, inflammation, and insulin resistance. Gastroenterology 132: 2169-2180, 2007.

3. Sing CF, Stengård JH and Kardia SL: Genes, environment, and cardiovascular disease. Arterioscler Thromb Vasc Biol 23: 1190-1196, 2003.

4. Loscalzo J and Welch G: Nitric oxide and its role in the cardiovascular system. Prog Cardiovasc Dis 38: 87-104, 1995.

5. Kraus WE: Genetic approaches for the investigation of genes associated with coronary heart disease. Am Heart J 140: S27-S35, 2000.

6. Hingorani $\mathrm{AD}$, Liang $\mathrm{CF}$, Fatibene J, Lyon A, Monteith S, Parsons A, Haydock S, Hopper RV, Stephens NG, O'Shaughnessy KM and Brown MJ: A common variant of the endothelial nitric oxide synthase (Glu298-> Asp) is a major risk factor for coronary artery disease in the UK. Circulation 100: 1515-1520, 1999.

7. Galavi HR, Saravani R, Alamdari AR, Ranjbar N, Damani E and Khodakhier TN: Evaluating the effect of the rs2229238 and the rs4845625 interleukin 6 receptor gene polymorphisms on body mass index and the risk of type 2 diabetes in an iranian study population. Int J High Risk Behav Addiction 5: e33289, 2016. 
8. Saravani R, Irani Z and Galavi HR: Evaluation of transcription factor 7 like 2 polymorphisms and haplotypes in risk of type 2 diabetes. Revista Romana de Medicina de Laborator 24: 423-430, 2016.

9. Saravani S, Miri H, Saravani R, Yari D, Nakhaee A and Mahjoubifard M: Association of catalase (rs7943316) and glutathione peroxidase-1 (rs1050450) polymorphisms with the risk of type 2 diabetes (T2DM). Mol Genet Microbiol Virol 30: 216-220, 2015.

10. Lowenstein CJ, Dinerman JL and Snyder SH: Nitric oxide: A physiologic messenger. Ann Intern Med 120: 227-237, 1994.

11. Karvonen J, Kauma H, Kervinen K, Rantala M, Ikäheimo M Päivänsalo M, Savolainen MJ and Kesäniemi YA: Endothelial nitric oxide synthase gene Glu298Asp polymorphism and blood pressure, left ventricular mass and carotid artery atherosclerosis in a population-based cohort. J Intern Med 251: 102-110, 2002.

12. Bressler J, Pankow JS, Coresh J and Boerwinkle E: Interaction between the NOS3 gene and obesity as a determinant of risk of type 2 diabetes: The atherosclerosis risk in communities study. PLoS One 8: e79466, 2013.

13. Bang H, Edwards AM, Bomback AS, Ballantyne CM, Brillon D, Callahan MA, Teutsch SM, Mushlin AI and Kern LM: Development and validation of a patient self-assessment score for diabetes risk. Ann Intern Med 151: 775-783, 2009.

14. Steinberg HO, Chaker H, Leaming R, Johnson A, Brechtel G and Baron AD: Obesity/insulin resistance is associated with endothelial dysfunction. Implications for the syndrome of insulin resistance. J Clin Invest 97: 2601-2610, 1996.

15. Marsden PA, Heng HH, Scherer SW, Stewart RJ, Hall AV Shi XM, Tsui LC and Schappert KT: Structure and chromosomal localization of the human constitutive endothelial nitric oxide synthase gene. J Biol Chem 268: 17478-17488, 1993.

16. Ferguson JF, Phillips CM, McMonagle J, Pérez-Martínez P, Shaw DI, Lovegrove JA, Helal O, Defoort C, Gjelstad IM, Drevon CA, et al: NOS3 gene polymorphisms are associated with risk markers of cardiovascular disease and interact with omega-3 polyunsaturated fatty acids. Atherosclerosis 211: 539-544, 2010.

17. Song Y, Manson JE, Tinker L, Rifai N, Cook NR, Hu FB, Hotamisligil GS, Ridker PM, Rodriguez BL, Margolis KL, et al: Circulating levels of endothelial adhesion molecules and risk of diabetes in an ethnically diverse cohort of women. Diabetes 56 1898-1904, 2007.

18. Meigs JB, Hu FB, Rifai $\mathrm{N}$ and Manson JE: Biomarkers of endothelial dysfunction and risk of type 2 diabetes mellitus. JAMA 291: 1978-1986, 2004

19. Möllsten A, Lajer M, Jorsal A and Tarnow L: The endothelial nitric oxide synthase gene and risk of diabetic nephropathy and development of cardiovascular disease in type 1 diabetes. Molecular genetics and metabolism 97: 80-84, 2009.

20. Li J, Tao F, Wu X, Tan Y, He L and Lu H: Polymorphic variation in manganese superoxide dismutase (MnSOD) and endothelial nitric oxide synthase (eNOS) genes contribute to the development of type 2 diabetes mellitus in the Chinese Han population. Genet Mol Res 14: 12993-13002, 2015.

21. American Diabetes Association: Standards of medical care in diabetes. Diabetes Care 27 (Suppl 1): S15-S35, 2004.

22. Saravani R, Galavi HR, Ranjbar N and Alamdari AR: ATP-binding cassette transporter A1 polymorphisms and haplotypes in risk of type 2 diabetes. Gene Cell Tissue 4: e43677, 2016.

23. Saravani S, Yari D, Saravani R and Ahmadabadi CA: Association of COL4A3 (rs55703767), MMP-9 (rs17576) and TIMP-1 (rs6609533) gene polymorphisms with susceptibility to type 2 diabetes. Biomed Rep 6: 329-334, 2017.

24. Mousavi M, Saravani R, Modrek MJ, Shahrakipour M and Sekandarpour S: Detection of toxoplasma gondii in diabetic patients using the nested PCR assay via RE and B1 genes. Jundishapur J Microbiol 9: e29493, 2016.

25. Haffner SM, Lehto S, Rönnemaa T, Pyörälä K and Laakso M: Mortality from coronary heart disease in subjects with type 2 diabetes and in nondiabetic subjects with and without prior myocardial infarction. N Engl J Med 339: 229-234, 1998.
26. Stern MP and Haffner SM: Body fat distribution and hyperinsulinemia as risk factors for diabetes and cardiovascular disease. Arteriosclerosis 6: 123-130, 1986.

27. Hink U, Li H, Mollnau H, Oelze M, Matheis E, Hartmann M, Skatchkov M, Thaiss F, Stahl RA, Warnholtz A, et al: Mechanisms underlying endothelial dysfunction in diabetes mellitus. Circ Res 88: E14-E22, 2001.

28. Johnstone MT, Creager SJ, Scales KM, Cusco JA, Lee BK and Creager MA: Impaired endothelium-dependent vasodilation in patients with insulin-dependent diabetes mellitus. Circulation 88: 2510-2516, 1993.

29. De Vriese AS, Verbeuren TJ, Van de Voorde J, Lameire NH and Vanhoutte PM: Endothelial dysfunction in diabetes. Br J Pharmacol 130: 963-974, 2000.

30. McVeigh G, Brennan G, Johnston G, McDermott BJ, McGrath LT, Henry WR, Andrews JW and Hayes JR: Impaired endothelium-dependent and independent vasodilation in patients with type 2 (non-insulin-dependent) diabetes mellitus. Diabetologia 35: 771-776, 1992.

31. Kahn BB and Flier JS: Obesity and insulin resistance. J Clin Invest 106: 473-481, 2000.

32. Haffner SM: Pre-diabetes, insulin resistance, inflammation and CVD risk. Diabetes Res Clin Pract 61 (Suppl 1): S9-S18, 2003.

33. Caballero AE, Arora S, Saouaf R, Lim SC, Smakowski P, Park JY, King GL, LoGerfo FW, Horton ES and Veves A: Microvascular and macrovascular reactivity is reduced in subjects at risk for type 2 diabetes. Diabetes 48: 1856-1862, 1999.

34. Balkestein EJ, van Aggel-Leijssen DP, van Baak MA, Struijker-Boudier HA and Van Bortel LM: The effect of weight loss with or without exercise training on large artery compliance in healthy obese men. J Hypertens 17: 1831-1835, 1999.

35. Rittig K, Hieronimus A, Thamer C, Machann J, Peter A, Stock J, Schick F, Fritsche A, Stefan N, Häring HU and Balletshofer B: Reducing visceral adipose tissue mass is essential for improving endothelial function in type 2 diabetes prone individuals. Atherosclerosis 212: 575-579, 2010.

36. Thameem F, Puppala S, Arar NH, Stern MP, Blangero J, Duggirala R and Abboud HE: Endothelial nitric oxide synthase (eNOS) gene polymorphisms and their association with type 2 diabetes-related traits in Mexican Americans. Diab Vasc Dis Res 5: 109-113, 2008.

37. Chen F, Li YM, Yang LQ, Zhong CG and Zhuang ZX: Association of NOS2 and NOS3 gene polymorphisms with susceptibility to type 2 diabetes mellitus and diabetic nephropathy in the Chinese Han population. IUBMB life 68: 516-525, 2016.

38. Conen D, Glynn RJ, Buring JE, Ridker PM and Zee RY: Renin-angiotensin and endothelial nitric oxide synthase gene polymorphisms are not associated with the risk of incident type 2 diabetes mellitus: A prospective cohort study. J Intern Med 263: 376-385, 2008.

39. Zintzaras E, Papathanasiou AA and Stefanidis I: Endothelial nitric oxide synthase gene polymorphisms and diabetic nephropathy: a HuGE review and meta-analysis. Genet Med 11: 695-706, 2009.

40. Makuc J and Petrovic D: No association between NOS2 and NOS3 polymorphisms and diabetic nephropathy in type 2 diabetics. Central European Journal of Biology 7: 404-410, 2012.

41. Chen Y, Huang H, Zhou J, et al: Polymorphism of the endothelial nitric oxide synthase gene is associated with diabetic retinopathy in a cohort of West Africans. Mol Vis 13: 2142-2147, 2007.

42. Zheleznyakova A, Vikulova O, Nosikov V and Shestakova M: The impact of polymorphisms in NOS3, APOB, KCNJ11, TCF7L2 genes on development of chronic kidney disease in type 2 diabetic patients. Exper Clin Endoc Diabetes 122: LB16, 2014.

43. Zakerjafari M, Mayali AM and Tavangar P: Evaluation of NOS3 gene rs1800779 polymorphism in Iranian patients affected by coronary-heart disease patients and normal individuals. Adv Biores 7: 16-21, 2016. 